\title{
Antibiotic Resistance and Detection of femH Gene in Staphylococcus Aureus Isolates from Raw Milk
}

\section{Pouya Khodadadi (PhD)}

Department of Microbiology, Islamic Azad University, Masjed-Soliman

Branch, Masjed-Soliman, Iran Mahdi bijanzadeh

Department of Medical Genetics, School of Medicine, Ahvaz Jundishapur University of Medical Sciences, Ahvaz, Iran

Akram Najafi (MSc)

Department of Marine Microbiology, Persian Gulf Marine Biotechnology Medicine Research Center, Bushehr University of Medical Sciences, Bushehr, Iran

Vajiheh Zarinpour (PhD) Department of Genetic, Faculty of Science, Islamic Azad University, Damghan Branch, Damghan, Iran

\section{Abdolali Moshfe (PhD)}

Cellular and Molecular Research Center, Yasuj University of Medical Sciences, Yasuj, Iran

\section{Hossein Ansari (PhD)}

Department of Microbiology, Islamic Azad University, Masjed-Soliman, Branch, Masjed-Soliman, Iran

\section{Corresponding author: Hossein} Ansari

Email: hosseinansari62@gmail.com

Tel: $+\mathbf{9 8 9 3 5 9 0 7 0 1 3 8}$

Address: Islamic Azad

University, Masjed-Soliman,

Branch, Masjed-Soliman, Iran

Received : 18 Oct 2014

Revised: 01 Jan 2015

Accepted: 04 Jan 2015

\section{ABSTRACT}

Background and Objective: Antibiotic-resistant Staphylococcus aureus strains have become a problem in treatment of infections caused by S. aureus. This study aimed to evaluate antibiotic resistance in $S$. aureus isolates from raw milk and detect femA gene in these isolates, as a confirmatory test for identification of $S$. aureus species.

Methods: This cross-sectional study was performed on 110 raw milk samples. After culture in Cooked Meat broth, presence of $S$. aureus in grown colonies was confirmed in accordance with Iranian National Standard, No. 1194. Antibiotic resistance was then evaluated according to guidelines recommenced by the Clinical Laboratory Standards Institute. FemA-specific polymerase chain reaction was performed on antibiotic-resistant strains using specific primers and standard strains to differentiate $S$. aureus from other species.

Results: S. aureus were found in 43 (39.09\%) of the 110 collected samples. Among these isolates, $79.07 \%$ and $76.75 \%$ were phenotypically resistant to penicillin and ceftazidime, respectively. In addition, the femA gene was detected in all isolates.

Conclusion: The results of this study show a high prevalence of resistance to penicillin and ceftazidime among $S$. aureus strains isolated from raw milk.

Keywords: Staphylococcus aureus, Antibiotic Resistance, Polymerase Chain Reaction. 


\section{INTRODUCTION}

Nowadays, Staphylococcus aureus is considered as one of the most important pathogens that cause food poisoning in hundreds of thousands of people around the world every year (1). The members of this genus has more than 20 species that have different habitats including skin, skin glands and mucous membranes of animals that can be spread via animal products such as cheese, milk and meat. S. aureus food poisoning is among the most prevalent types of poisoning in most countries $(2,3)$. The variety of the bacteria habitats and imprudent and uncontrolled use of broad-spectrum antibiotics such as third generation cephalosporins, macrolides and fluoroquinolones are the contributing factors responsible for emergence of antibiotic (methicillin, vancomycin)resistant $S$. aureus strains $(4,5)$. FemA is a $S$. aureus-specific gene that encodes one of the several factors necessary for methicillin resistance. Therefore, this essential gene could be isolated from methicillin-resistant $S$. aureus strains (MRSA) $(6,7)$. The femA gene encodes a $48 \mathrm{kDa}$ broad-spectrum protein that is involved in metabolism, cell wall synthesis, growth and activity of bacteria in culture medium. Mutation or inactivation of fem genes $(\mathrm{A}, \mathrm{B}, \mathrm{C})$ reduces resistance to methicillin $(8,9)$. Although presence of MecA chromosomal gene is required for synthesis of penicillin binding protein 2a (PBP2a), two groups of factors are involved in regulation of its expression. The first group includes products of genes such as femA. The second group consists of environmental conditions such as osmolarity of culture medium (such as $\mathrm{NaCl}$ ), body temperature, and incubation time (10). Most $S$. aureus strains are heterogeneously resistant to several antibacterial agents such as beta-lactams, aminoglycosides, macrolides, clindamycin and tetracycline $(6,11)$. Therefore, this study aimed to evaluate antibiotic resistance of $S$. aureus isolates from raw milk and detect the femA gene for molecular identification of $S$. aureus.

\section{MATERIAL AND METHODS}

This descriptive cross-sectional study was performed on 110 raw milk samples collected from milk tankers and traditional cattle farms in cities of Mamasani and Rostam from April to August 2012. The samples were poured into sterile containers and transferred to Foodstuff Laboratory of Mamasani and rostam(Iran) at Faculty of Paramedical Sciences under cold condition. After homogenization of the samples with normal saline under sterile conditions and enrichment using Cooked Meat broth (PBL Co, UK, Cat No.D2013) with $7.5 \% \mathrm{NaCl}$, incubation was done at $37^{\circ} \mathrm{C}$ for 48 hours. Then, the grown bacteria were subcultured on Baird-Parker agar with added egg yolk. Diagnostic and differential tests such as coagulase, DNase, mannitol, VogesProskauer, catalase, and Gram staining were carried out for all isolates obtained in accordance with the Iranian National Standard No. 1194. The isolates were stored in tryptic soy broth (TSB) containing 15\% glycerol at $20{ }^{\circ} \mathrm{C}$ until molecular and antibiotic susceptibility testing. Antibiotic susceptibility of isolates was evaluated by disk diffusion method according to guidelines recommended by the Clinical and Laboratory Standards Institute (12). Fourteen antibiotics including penicillin $(10 \mu \mathrm{g})$, chloramphenicol $(30 \mu \mathrm{g})$, ceftazidime $(30 \mu \mathrm{g})$, erythromycin $(15 \mu \mathrm{g})$, vancomycin $(30 \mu \mathrm{g})(12,13)$, gentamicin $(10$ $\mu \mathrm{g})$, rifampin $(30 \mu \mathrm{g})$, trimethoprim $(5 \mu \mathrm{g})$, ciprofloxacin $(5 \quad \mu \mathrm{g})$, oxacillin $(1 \quad \mu \mathrm{g} g)$ $(12,14)$, tetracycline $(30 \mu \mathrm{g})$, cloxacillin $(5$ $\mu \mathrm{g})$, ceftriaxone $(30 \mu \mathrm{g})$ and cephalothin $(30$ $\mu \mathrm{g})$ were purchased from Padtan Teb Co. for this purpose. The results were reported as susceptible, moderately susceptible and resistant after 24 hours of incubation at $37{ }^{\circ} \mathrm{C}$ (12). Standard S. aureus strain ATCC 29213 (purchased from Bank of Bacteriology of Tarbiat Modarres University, Tehran) was used for quality control of antibiotic discs.

$S$. aureus isolates cultured in BHI for 24 hours were used for DNA extraction. DNA was extracted using the phenol-chloroform method. Genomic DNA was electrophoresed on $1 \%$ agarose gel and concentration of DNA was measured at $260 \mathrm{~nm}$ using transilluminator device to analyze the quality of the purified genome. The following species primers were used for amplification of the femA gene: femA-F: 5'- AACTTAGGATTTGAACATACTGGA -3' femA-R: 5'- GACGTTTACCTTCTTCAATCTT -3' The primers were designed based on the genome of $S$. aureus, checked on the Blast 
website, and then purchased from CinnaGen Co. S. aureus ATCC29213 and sterile distilled water were used as the positive and negative control, respectively. PCR reaction solution with final volume of $25 \mu$ l contained PCR Buffer 10X $(5 \mu \mathrm{l})$, dNTP mixture $(2 \mu \mathrm{l})$, $\mathrm{MgCl}_{2}(1.5 \mu \mathrm{l})$, Taq DNA polymerase $(1 \mu \mathrm{l})$, each of the primers $(0.5 \mu \mathrm{l})$, DNA template $(5$ $\mu \mathrm{l})$ and $9.5 \mu \mathrm{l}$ sterile double-distilled water. Later, PCR was performed using a thermocycler (Mastercycler Gradient, Eppendorf, Germany) beginning with 5 minutes initial denaturation at $95 \circ \mathrm{C}$, followed by 30 cycles of denaturation at $94{ }^{\circ} \mathrm{C}$ for 1 minute, annealing at $60{ }^{\circ} \mathrm{C}$ for $1 \mathrm{~min}$, extension at $72{ }^{\circ} \mathrm{C}$ for 1 minute, and final extension at $72{ }^{\circ} \mathrm{C}$ for 10 minutes. The final PCR product was electrophoresed on $1.5 \%$ agarose gel and then analyzed under UV-light after staining with ethidium bromide. Statistical analysis of data was carried out in SPSS software version 18, using Fisher's exact and Chi-square tests. P-values less than 0.05 were reported as statistically significant.

\section{RESULTS}

According to biochemical tests, 43 $(39.09 \%)$ of the 110 samples collected were contaminated with $S$. aureus. The presence of the femA gene in all positive isolates were confirmed by the PCR experiment and observing a $499 \mathrm{bp}$ band (Figure 1). Antibiotic susceptibility testing of $S$. aureus isolates showed that the highest level of resistance was to ceftazidime $(79.07 \%)$ and penicillin $(76.75 \%)$. On the other hand, the lowest level of resistance was observed against gentamicin $(16.28 \%)$ and all isolates were susceptible to vancomycin. Simultaneous antibiotic resistance to multiple antibiotics including ceftazidime, penicillin, cloxacillin, oxacillin, trimethoprim, ceftriaxone, and cephalothin was observed in $f e m A$ gene-containing strains (Table 1).

Table 1- Antibiotic susceptibility patterns of $S$. aureus isolates from raw milk samples using the disk diffusion method

\begin{tabular}{|c|c|c|c|}
\hline & Susceptible (\%) & $\begin{array}{l}\text { Moderately } \\
\text { susceptible (\%) }\end{array}$ & Resistant (\%) \\
\hline Penicillin & $8(18.60)$ & $2(4.65)$ & 33(76.75) \\
\hline Chloramphenicol & $28(65.12)$ & $4(9.30)$ & $11(28.58)$ \\
\hline Ceftazidime & $0(0)$ & $9(20.93)$ & $34(79.07)$ \\
\hline Erythromycin & $25(58.14)$ & $10(23.26)$ & $6(13.95)$ \\
\hline Vancomycin & $43(100)$ & $0(0)$ & $0(0)$ \\
\hline Gentamicin & $30(69.77)$ & 6(13.95) & $7(16.28)$ \\
\hline Rifampin & $27(62.79)$ & $3(6.98)$ & $13(30.23)$ \\
\hline Trimethoprim & $23(53.49)$ & $7(16.28)$ & $13(30.23)$ \\
\hline Ciprofloxacin & $21(48.84)$ & $10(23.26)$ & $12(27.9)$ \\
\hline Oxacillin & $23(53.49)$ & $5(11.63)$ & $15(34.88)$ \\
\hline Tetracycline & $26(60.47)$ & $7(16.28)$ & $10(23.26)$ \\
\hline Cloxacillin & $7(16.28)$ & $11(25.58)$ & $25(58.14)$ \\
\hline Ceftriaxone & $20(46.51)$ & $14(32.56)$ & $9(20.93)$ \\
\hline Cephalothin & $27(62.79)$ & $7(16.28)$ & $9(20.93)$ \\
\hline
\end{tabular}

Figure 1- Electrophoresis of PCR products

Column 1: 100 bp Marker bp, column 2: positive control (standard strain ATCC29213), column 3-5: femA gene 499 bp bands, column 6: negative control

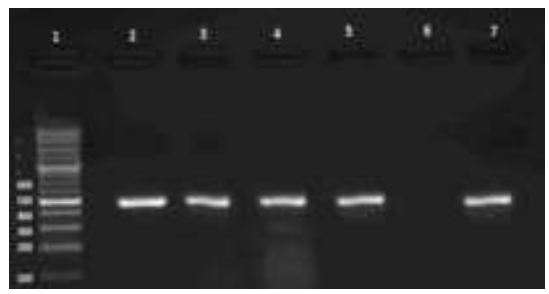

\section{DISCUSSION}

$S$. aureus can colonize on skin and mucous membranes of humans and animals (as the primary reservoir). Thus, these bacteria can easily enter foodstuffs that require processing (meat, milk and vegetables) during preparation process. Most of the known species of these widely distributed bacteria in nature are saprophytes and nonpathogenic, but some of them are pathogenic for humans and animals. Presence of the bacteria in food and dairy products were investigated in the late nineteenth century (13). Bennet (1914) showed the symptoms and effects of food poisoning by drinking milk contaminated with Staphylococcus (13). S. aureus, a common cause of food poisoning and infections caused by these bacteria, have a high prevalence in different places such as hospitals, which often have serious consequences despite antibiotic treatment. Therefore, determination of antibiotic resistance patterns of $S$. aurous isolates from different samples is essential, because it could be useful for selection of suitable drugs for treatment of the infections. 
In this study, microbiological and biochemical methods showed that $43(39.09 \%)$ of 110 milk samples collected were contaminated with $S$. aureus. The highest level of antibiotic resistance was observed against ceftazidime (79.07\%) and penicillin (76.75\%), while all isolates were susceptible to vancomycin. Increasing drug resistance in these bacteria and the consequent spread of infections, have drawn the attention of the scientific community. Study of Dibaj et al. investigated antibiotic susceptibility of 115 nasal $S$. aureus isolates from children in the city of Isfahan by the disc diffusion method, and found that all isolates were vancomycin-resistant (14), which is consistent with the results of the present study in regards to vancomycin resistance. Study of Farzana et al. was conducted on 50 raw milk samples collected from city of Multan in Pakistan, and reported that $40 \%$ of the samples were contaminated with $S$. aureus (15). Another study in Brazil on 162 raw milk samples collected from five cattle farms, reported that $70.4 \%$ of the samples were contaminated with $S$. aureus (16). In Nigeria, Suleiman et al. examined 339 milk samples obtained from animals with mastitis and reported that 103 samples (30.9\%) were contaminated with $S$. aureus, while $35.6 \%$ of the isolates were oxacillinresistant (17). These results are slightly different from the results obtained in the present study, which could be due to differences in climatic conditions and method of raw milk collection. Daka et al. found $78 \mathrm{~S}$. aureus isolates in 160 raw milk samples collected in Ethiopia. All the isolates were resistant to penicillin $\mathrm{G}$ and the highest level of resistance was observed against amoxicillin (70.9\%), penicillin $(67.9 \%)$, oxacillin $(60.3 \%)$ and vancomycin $(38.5 \%)$ (18). Joshi et al. studied 400 milk samples and found 119 (29.7\%) S. aureus isolates with $97.47 \%$, $94.95 \%, 91.59 \%$ and $89.9 \%$ susceptibility to ciprofloxacin, gentamicin, ceftriaxone and tetracycline, respectively (19). These results are inconsistent with the findings of the present study, which could be related to the type of antibiotics used. Another study in Brazil, found 105 contaminations with $S$. aureus from a total of 465 milk samples. The highest rate of antibiotic resistance was observed against ceftazidime $(\mathrm{n}=41,89.1 \%)$ and cloxacillin ( $\mathrm{n}=41,89.1 \%)$ (20). Poorfeiz et al. conducted a study in Tabriz on 220 raw milk samples and reported 20 samples with $S$. aureus contamination. The percentage of antibiotic resistance to tetracycline, amoxicillin, gentamicin and erythromycin were reported as 35\%, 5\%, 45\% and $40 \%$, respectively. Moreover, all samples were sensitive to methicillin and vancomycin (21). These findings are consistent with the results obtained in the present study in terms of susceptibility to vancomycin, ceftazidime, cloxacillin and tetracycline. According to NCCLS recommendations, oxacillin could be used to determine susceptibility to methicillin. Oxacillin was used instead of methicillin in this study for identification of MRSA strains, since oxacillin maintains its activity for longterm and is more stable than methicillin in vitro $(6,11,22)$. Thus, oxacillin is more efficient than methicillin in identification of heteroresistant strains (MRSA strains with lower numbers and growth rates in a microbial population compared to nonresistant strains). Although oxacillin resistance is rare in $S$. aureus strains, some of them could be resistant to methicillin or oxacillin and lack the gene coding for antibiotic resistance (12). The inconsistency in the frequency and extent of antimicrobial resistance reported by studies in Iran and rest of the world (15, 17-21) could be due to different of the techniques used, geographic area, and type of samples collected and common antibiotics prescribed during a particular period of time. High level of contamination in raw milk could have several reasons including cross-contamination caused by preparation by hand and failure to comply with code of hygienic practices for the milking process. Thus, presence of antibiotic-resistant strains in milk could pose a serious threat to public health. The percentages obtained for resistant strains are variable in different studies, which could be related to method of identification of the strains and type of samples studied. The PCR experiment in the present study showed that 43 isolates had the femA gene. Study of Janesh manikandan et al. in India detected the femA gene in all MRSA isolates (6). Li et al. found a similar finding in a study on MRSA isolates and reported increased expression of this gene in MRSA strains compared to methicillin-susceptible $S$. aureus (MSSA) strains (9). Kobayash et al. detected femA and $\mathrm{femB}$ gene in $237 \mathrm{~S}$. aureus isolates and claimed that these two genes could be used for identification of MRSA strains (23). These 
results are consistent with the results of the present study, which indicate the presence of this gene in all resistant and susceptible $S$. aureus strains. In fact, this $S$. aureus-specific gene is considered an essential factor for methicillin resistance.

\section{CONCLUSION}

There is a high prevalence of antibiotic resistance in $S$. aureus isolates from milk.

\section{REFERENCES}

1. Paterson GK, Morgan FJE, Harrison EM, Peacock SJ, Parkhill J, Zadoks RN, et al. Prevalence and properties of mecC methicillin-resistant Staphylococcus aureus(MRSA) in bovine bulk tank milk in Great Britain. J Antimicrob Chemother. 2014; 69(3): 598-602.

2. Le Loir YL, Baron F, Gautier M. Staphylococcus aureusand food poisoning. Genet Mol Res. 2003; 2(1): 63-76.

3. Pradipta A, Sidik R, Helmi Effendi M. Isolation and identification of Staphylococcus aureus from Raw Milk Resistant Against Non $\beta$-Lactam Antibiotics. Agro veteriner. 2013; 1(2): 99-109.

4. Cook PP, Catrou P, Gooch M, Holbert D. Effect of reduction in ciprofloxacin use on prevalence of methicillin resistant Staphylococcus aureusrates within individual units of a tertiary care hospital. Journal of Hospital Infection. 2006; 64(4): 348-351.

5. Kot B, Binek T, Piechota M, Wolska KM, Zdunek E, Płatkowska K. Virulence factors and ability of staphylococci from bovine milk and the cowshed environment to biofilm formation. Journal of Veterinary Sciences. 2013; 16(4): 639-645.

6. Ganesh Manikandan S, Hemalatha M, Lakshminarasimhan $\mathrm{C}$, Thajuddin $\mathrm{N}$. Isolation and amplification of femA gene from MRSA isolates. IJPBS. 2011; 2(3): 28-35.

7. Sakoulas G, Gold HS, Venkataraman L, DeGirolami PC, Eliopoulos GM, Qian Q. Methicillin-resistant Staphylococcus aureus: comparison of susceptibility testing methods and analysis of mecA-positive susceptible strains. J Clin Microbiol. 2001; 39(11): 3946-51.

8. Paterson GK, Harrison EM, Holmes MA. The emergence of mecC methicillin resistant Staphylococcus aureus. Trends in Microbiology. 2014; 22(1): 42-47.

9. Li X, Xiong Y, Fan X, Feng P, Tang H, Zhou T. The role of femA regulating gene on methicillinresistantStaphylococcus aureus clinical isolates, Médecine et Maladies Infectieuses. 2012; 42(5): 218225.

10. Farhadian A, Behzadian Nejad Q, Najar peerayeh SH, Rahbar M, Vaziri F. Determination of Vancomycin and Methicillin Resistance in Clinical Isolates of Staphylococcus aureusin Iranian Hospitals. British Microbiology Research Journal. 2014; 4(4): 454-461.

\section{ACKNOWLEDGMENTS}

The authors would like to thank Dr. Mohammad Kargar for his valuable guidance and all those who helped them in conducting this study (especially Mr. Heshmat-Allah Sajedi, the respected manager of Human Resources of Dehkhoda Sugarcane AgroIndustry Co.).

\section{CONFLICT OF INTEREST}

We have no conflict of interest to declare.

11. Leanne J, Jane M, Naledi BM. Rapid differentiation of Staphylococcus aureus, Staphylococcus epidermidis and other coagulasenegative staphylococci and methicillin susceptibility testing directly from growthpositive blood cultures by multiplex real-time PCR. Journal of Medical Microbiology. 2010; 59(Pt 12):145661. doi: 10.1099/jmm.0.023168-0.

12. Clinical and Laboratory Standards Institue. Performance standards for antimicrobial susebtibility testing: 17th ed. Informathional supplement. CLSI document M100-A20. Clinical and Laboratory Standard Institue, wayne, PA. 2012.

13. Dulon M, Haamann F, Peters C, Schablon A, Nienhaus A. MRSA prevalence in European healthcare settings: a review. BMC Infect Dis. 2011; 11: 138. doi: 10.1186/1471-2334-11-138.

14. Dibaj R, Shoaei P, Hashemi A, Abass Daei N, Shojaei H. Study of Prevalence and Characteristics of Staphylococcus aureus and CA-MRSA Nasal Colonization in 2-5 Years Old Children in Isfahan. Iran J Med Microbiol. 2014; 8(3): 22-30.

15. Farzana K, Syed Nisar HS, Farzana J. Antibiotic resistance pattern against various isolates of Staphylococcus aureusfrom milk samples. Journal of Research (Science), Bahauddin Zakariya University, Multan, Pakistan. 2004; 15(2): 145-151.

16. Rall VLM, Vieira FP, Rall R, Vieitis RL, Fernandes $\mathrm{Jr}$, Candeias JMG, et al. PCR detection of staphylococcal enterotoxin genes in Staphylococcus aureusstrains isolated from raw and pasteurized milk, Veterinary Microbiology,2008; 132(3-4): 408-13.

17. Suleiman AB, Umoh VJ, Kwaga JKP, Shaibu SJ. Prevalence and antibiotic resistance profiles of Methicillin resistant Staphylococcus aureus (MRSA) isolated from bovine mastitic milk in Plateau State, Nigeria. International Research Journal of Microbiology (IRJM). 2012; 2(8): 264-270.

18. Daka D, G/Silassie S, Yihdego D. Antibioticresistance Staphylococcus aureusisolated from cow's milk in the Hawassa area, South Ethiopia. Ann Clin Microbiol Antimicrob. 2012; 11: 26. doi: 10.1186/14760711-11-26.

19. LoK R, Joshi LR, Devkota SP. Methicillin resistance Staphylococcus aureus (MRSA) in cattle; Epidemiology and zoonotic implications. Int J Appl Sci Biotechnol. 2014; 2(1): 29-33. 
20. Lucianne Leigue dos S, Cibeli V, Gabriela F Luciana KO, Adalberto VG. Antimicrobial susceptibilityofstrainsStaphylococcus aureusand Staphylococcus coagulase-negativeisolated fromcows' milk with mastitis in the West of Paraná, Brazil. Enciclopédia Biosfera. 2013; 9(17): 213-223.

21. Hosseinpour Feizi MA, Zarrini Gh, Tahmasebi M. Evaluation of Protein A Gene Tandem Repeat Polymorphism of Staphylococcus aureusIsolated From Bovine Mastitis in Tabriz. Jundishapur J Microbiol. 2013, 6(6): 1-4.
22. Buyukcangaz E, Kahya S, Sen A, Intas KS, Eyigor A, Temelli S, Carli KT. MecA Gene Prevalence in Staphylococcus aureusIsolates from Dairy Cows in Turkey. J BIOL ENVIRON SCI. 2013; 7(21): 183-190.

23. Kobayashi $\mathrm{N}, \mathrm{Wu} \mathrm{H}$, Kojima K, Taniguchi K, Urasawa S, Uehara N, et al. Detection of mecA, femA, andfemB genes in clinical strains of staphylococci using polymerase chain reaction. Epidemiol Infect. 1994; 113(2): 259-66. 